\title{
14209 重度障害者向け稼働位置決め支援装置
}

\section{Support system of positioning operation for severely handicapped persons}

\section{○一察田. 行晃（神奈川工大）}

高橋 良彦（神奈川工大）

Yukiteru Kubota, Kanagawa:Inst: of Tech., 1030, Shimo-Ogino, Atugi, kanagawa, 243-0292, Japan Yoshihiko Takahashi, Kanagawa Inst. of Tech., 1030, Shimo-Ogino, Atugi, kanagawa, 243-0292, Japan

A positioning system of a PC display or an input device is proposed for a physically handicapped person. A PIC microcomputer is used to fabricate a small controller. The experiments on human's psychological responses were conducted using a GSR sensor.

\section{1. 緒言}

寝たきりや、何らかの障害によって身体の自由の利かない 方がディスプレイや入力装置の位置を自分の好きな位置に移 動する事は困難であり、この移動作業は介護者の負担となっ ている。そこで介護者と障害者の負担を軽減するために使用 者の動きに合わせて稼働し、常に使用者にとって最適な位置 にディスプレイや入力装置を稼働させるシステムの提案を行 う。

本論文では、皮膚電気反射（GSR）を用い、ロボットが人 間に与える影響を生理心理学 $[1,2]$ から検証を行う。本研究室 ではこれまで可能な限り音を立てずにロボットを動かし、視 覚情報によってロボットが人間に与える心理的な影響を検証 してきた[3]、本研究では音に対する反応を主に扱っている。

2. 提案するロボットシステムのコンセプト

Fig.1 に提案する稼動位置決め支援装置の概要図を示す。本 装置はベッドの横に置くことを想定しているので車椅子など でアプローチしたときに装置の固定具が車椅子と干涉しない 様にするためシステム全体を小型化する必要がある。その為 パーソナルコンピュータの代わりに PIC マイゴンを使用し制 御を行う。また、入力装置は現在介護支援装置で頻繁に使用 されている物との干涉を防ぐために、昨年度本研究室で製作 された、ファイバセンサを用いた非接触型の入力装置を使用 する[4]。

\section{3. パーソナルスペース}

人間は誰でも、他者に侵入されると不快になるパーソナル スペースと言われる空間を持っている[1,2]。Fig.2に示すよう にパーソナルスペースは、一般的に前後を長径、左右を短径 とする棈円状に広がり：後方よりも前方が広くなっていると 考えられている。その大きさには個人差があり、接近する相 手や状況にようても変化する。好意を持つ人にはパーソナル スペースを広げ、そうでない人には狭めるという距離のコン トロールが無意識のうちに行われているが、この相手との距 離を対人距離と言う。

\section{4. 皮膚電気反射（GSR）測定装置構成}

Fig. 3 に皮膚電気反射（GSR）測定装置の構成を示す。

GSR 测定装置には竹井機器工業侏製を用いた。騒音計には 懒カスタム製デジタル騒音計 SL-1360を用いた。音源には風 船と DC モータを用いた。DC モータは田宮模型 6 速ギヤボ

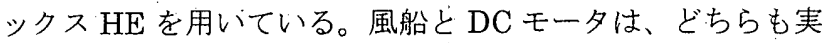
験者の手元のスイッチで破裂・駆動を行えるようにした。

\section{5. 皮膚電気反射 (GSR) 測定実験}

Fig.3に示した測定装置を使用して皮膚電気反射（GSR）の 測定実験を行った。Fig.4 は奉際に行った実験の様子である。 実験は鉄筋コンクリート製 3 階建ての建物の 2 階にある研究

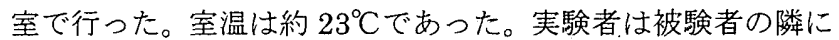
$1 \mathrm{~m}$ 程度離れて座った。被験者には机（綐 $0.86 \mathrm{~m}$ 、ついたて の間隔 $0.9 \mathrm{~m}$ 、高さ $0.73 \mathrm{~m}$ ) を挟んで壁のほうを向いてもら い左右についたてを立て意図しない視覚的な情報の進入を 防いだ。壁と被験者の距離は $1.2 \sim 1.4 \mathrm{~m}$ 程度である。音源 である風船と DC モー夕被験者の後方 $1 \mathrm{~m}$ 及び $0.5 \mathrm{~m}$ の位圆 にある椅子に乗せて設置した。測定装置をつけて安定するの を待ってから測定を開始した。この時に平常時（基準とする） をとっておき今後の比較対照として使用する。波形が安定し た後、「風船を割る音」「DC モータの駆動音」で音による刺 激を被験者に与え反応を見た。“平常時の基線よりも絶対值で 2 倍以上の反応があったとき動摇したと判断した。以上の様 な実験をTable.1 に示した被験者 5 名に対して行った。

\section{6. 皮膚電気反射 (GSR) 測定実験結果}

Fig. 5 に被験者の後方 $1 \mathrm{~m}$ 、パーソナルスペースの外側と思 われる位置に音源を置いた時の皮膚電気反射（GSR）測定実 験の結果を示した。結果より風船の破裂音に大きく反応して いる事が分かる。また、DC モータの駆動音に対しては一回 目より二回目、三回目と回数を重㸚た方が皮膚電気反射 (GSR）の反応が小さくなっていることが分かる。

Fig.6 に被験者の後方 $0.5 \mathrm{~m}$ 、パーソナルスペースの内側と 思われる位置に音源を置いた時の皮膚電気反射（GSR）測定 “実験の結果を示した。Fig.5 と比較すると終始、皮膚電気反射 （GSR）の波形が不安定なのが見て取れる。また、DC モー 夕の駆動音に対しても 3 回とも大きな反応を示していること がわかる。これは他の 4 名の被験者に対しても同様な結果を 得た。

7. 結言

重度障害者向け稼働位置決め支援装置の提案を行った。ま た皮膚電気反射 (GSR) 測定装置を用いて人間・ロボット間 のパーソナルスペースの検証を行った。この結果、ロボット に対してもパーソナルスペースの外側と内側では反灾が異な ることが分かった。以上の事からロボットがパーソナルスペ 一スの内側にあると人間は不快に感じると考えられ、ロボッ トをパーソナルスペースの内側で使用するときは何らかの対 策が必要であると考える。

\section{参考文献}

[1]大坊郁夫,しぐさのコミュニケーション,サイエンス社 (1998)

[2]松尾太加志, コミュニケーションの心理学,ナカニシヤ出版 (1999)

[3]高橋良彦、長谷川尚哉、高橋勝美、畠山卓郎、ヘッドスペースポ インターを利用した食事支援ロボット用ヒューマンインターフェ イスの評価実験とロボット動作に対する人閒の心理反忘、設計工学、 日本設計工学会, 37 巻, 3 号、p.122 128 (2002)

[4]Y.Tkahasi, and S.Suzukawa, Eating Assist Robot with Easy Human Interface for. Severely Handicapped Person, Proc. Control, Automation, Robotics and Vision (ICARCV2002),p.1013-1018 (2002) 
Human interface with fiber unit

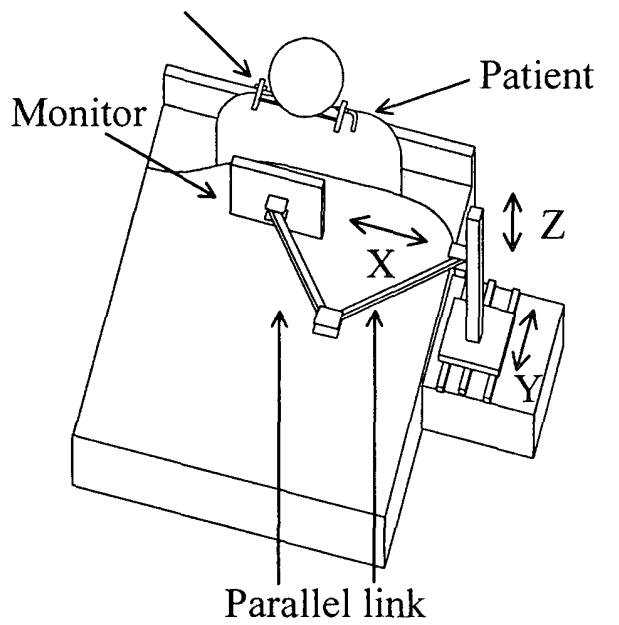

Fig.1 Support system of positioning operation for severely handicapped persons

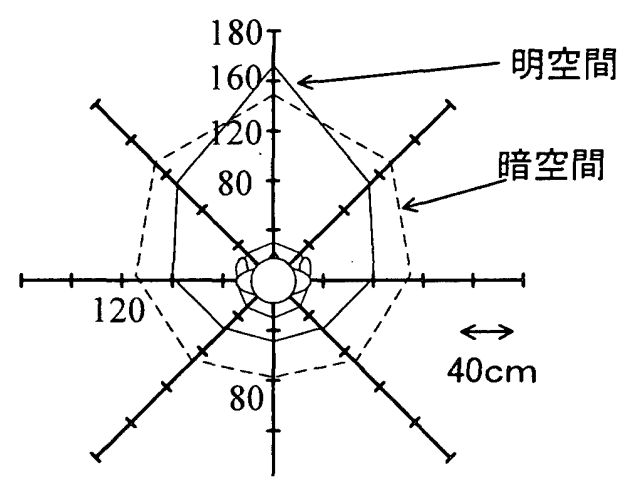

大坊郁夫著 しぐさのコミュニケーション

サイエンス社 1998 年

Fig.2 Personal space

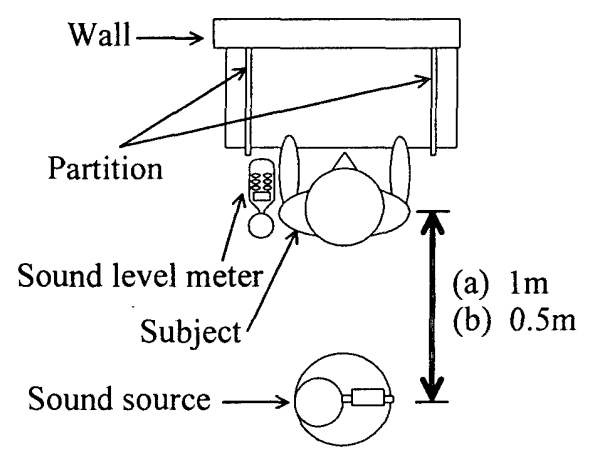

Fig.3 Experiments on GSR measurement

Table.1 Subject data

\begin{tabular}{|l|c|c|c|c|}
\hline & Height(cm) & Weight(kg) & Age & Sex \\
\hline Subject-A & 168.5 & 65 & 25 & Man \\
\hline Subject-B & 180 & 105 & 22 & Man \\
\hline Subject-C & 159 & 60 & 24 & Man \\
\hline Subject-D & 164.5 & 50 & 22 & Man \\
\hline Subject-E & 165 & 70 & 33 & Man \\
\hline
\end{tabular}

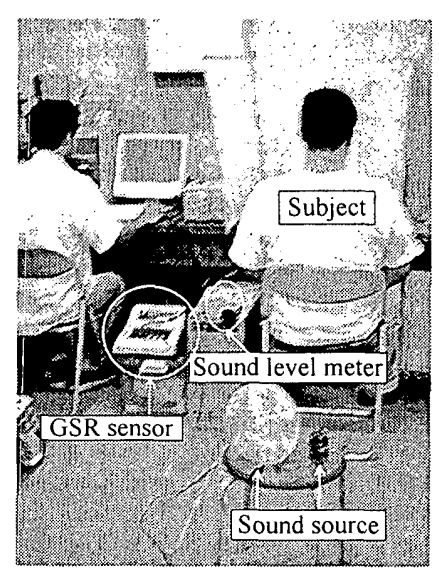

Fig.4 Photograph of GSR measurement

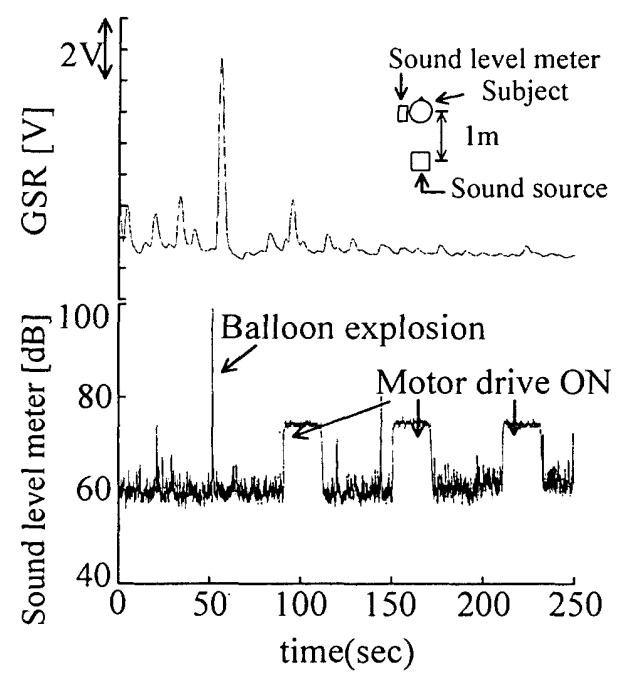

Fig.5 Experimental results on GSR measurement (Subject-A , 1 m)

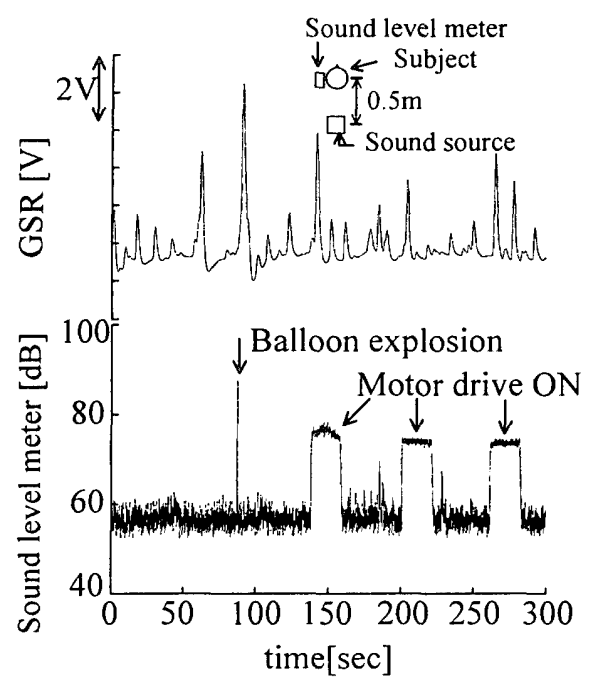

Fig.6 Experimental results on GSR measurement (Subject-A，0.5m) 